\title{
Biotic and Abiotic Factors Associated with Colonies Mortalities of Managed Honey Bee (Apis mellifera)
}

\author{
Boyko Neov $^{1}$, Ani Georgieva ${ }^{2}$, Rositsa Shumkova ${ }^{3}$, Georgi Radoslavov $^{1}$ (D) and \\ Peter Hristov 1,*(D)
}

1 Department of Animal Diversity and Resources, Institute of Biodiversity and Ecosystem Research, Bulgarian Academy of Sciences, “Acad. G. Bonchev” Str., Bl. 25, Sofia 1113, Bulgaria; boikoneov@gmail.com (B.N.); gradoslavov@gmail.com (G.R.)

2 Department of Pathology, Institute of Experimental Morphology, Pathology and Morphology and Anthropology with Museum, Bulgarian Academy of Sciences, Sofia 1113, Bulgaria; georgieva_any@abv.bg

3 Research Centre of Stockbreeding and Agriculture, Agricultural Academy, Smolyan 4700, Bulgaria; rositsa6z@abv.bg

* Correspondence: peter_hristoff@abv.bg; Tel.: +35-929-792-327

Received: 2 November 2019; Accepted: 9 December 2019; Published: 10 December 2019

\begin{abstract}
Despite the presence of a large number of pollinators of flowering plants worldwide, the European honey bee, Apis melifera, plays the most important role in the pollination of a number of crops, including all vegetables, non-food crops and oilseed crops, decorative and medical plants, and others. The experience of isolated cases of complete extinction of honey bees in individual regions has shown that this phenomenon leads to a dramatic pollination crisis and reduced ability or even total inability to grow insect-pollinated crops if relying solely on native, naturally occurring pollinators. Current scientific data indicate that the global bee extinction between the Cretaceous and the Paleogene (Cretaceous-Tertiary) occurred, which led to the disappearance of flowers because they could not produce viable fruit and germinate due to lack of pollination by bees or other animals. From the Middle Ages to the present day, there has been evidence that honey bees have always overcome the adverse factors affecting them throughout the ages, after which their population has fully recovered. This fact must be treated with great care given the emergence of a new, widespread stress factor in the second half of the 20th century-intoxication of beehives with antibiotics and acaricides, and treatment of crops with pesticides. Along with acute and chronic intoxication of bees and bee products, there are other new major stressors of global importance reducing the number of bee colonies: widespread prevalence of pathogenic organisms and pest beetles, climate change and adverse climatic conditions, landscape changes and limitation of natural habitats, intensification of agricultural production, inadequate nutrition, and introduction of invasive species. This report summarizes the impact of individual negative factors on the health and behavior of bees to limit the combined effects of the above stressors.
\end{abstract}

Keywords: Apis mellifera; honey bee colony losses; biotic factors; abiotic factors

\section{Introduction}

The European honey bee, Apis mellifera L. (Hymenoptera: Apidae) has been managed for millennia [1]. The species was domesticated by the ancient Egyptians around 2600 BC [2]. Since then, bees have been used as a source of unique, natural, multifunctional products (basically honey and wax). However, the more significant ecological function of the species is related to the pollination of a wide range of agricultural and wild plant species. The honey bee is one of about 200,000 existing species of plant pollinators [3]. Approximately 84\% of the crops grown in Europe are dependent on insect 
pollination [4]. The only major exception is grain crops that are wind-pollinated. Bees, both wild and managed, provide about $80 \%$ of the insect pollination of flowering plants [5]. Among them, the honey bee plays the most important role in the process, especially in the pollination of apple, cherry, small grapes, kiwi, broccoli, carrots, cauliflower, celery, cucumber, onion, pumpkin, legumes, sunflower, and many others.

The role of A. mellifera as a pollinator in natural habitats is important for several reasons. First, animal-mediated pollination represents vital ecosystem maintenance, i.e., $87.5 \%$ of flowering plant species are pollinated by animals [6]. It is well known that the honey bee is considered as a super generalist, which provides a vital role in the functioning of many terrestrial ecosystems [7]. Unlike other pollinators, which have declined significantly in recent years, mainly as a result of habitat loss, A. mellifera populations can overcome these disorders [8]. The recent increases in the mortality of managed A. mellifera colonies in some parts of the world (USA) may increase the feral population, which is more susceptible mainly to Varroa mite [9]. In some countries, the introduction of populations A. mellifera has led to competition with other pollinators [10,11]. A typical example is Australia, where beekeepers are restricted to use agricultural land but not national parks for this very reason [12]. Given the importance of honey bees for the nourishment of humankind, the reducing of the number of bee colonies in Europe and America has been met with increasing concern in recent decades. Some of the published materials describe the unusual and somewhat tragic consequences of a future crisis in honey bee populations and other pollinator species $[13,14]$. Other studies have linked the problem with the degradation of natural ecosystems and the persistent tendency to lose ever-increasing amounts of the planet's biodiversity $[15,16]$.

The purpose of this report is to summarize and analyze data published in the scientific literature on the causes, drivers, and conditions associated with the poor health status and death of bees and bee colonies.

\section{Historical Occurrences of Honey Bee Decline}

\subsection{Prehistoric Extinction Event}

There have been known cases of complete bee extinction or population crises. It has been established that prehistoric mass extinction of bee species from the Xylocopinae colony took place during the transition between the Cretaceous and Paleogene geological periods, about 65.5 million years ago [17]. The period has left a characteristic imprint on geological layers-a thin clay layer known as the $\mathrm{K}-\mathrm{Pg}$ (Cretaceous-Paleogene) or K-T boundary. On the base of sequence and phylogenetic analysis of two mitochondrial COI (cytochrome oxidase subunit 1) and cytb (cytochrome b) and two nuclear genes, F1 and F2 Elongation Factor- $1 \alpha($ EF-1 $\alpha)$ of Xylocopinae tribe [17], the authors suggested the disruption of many plant-insect relationships at that time, which had a negative effect on the bees. The Cretaceous-Paleogene mass extinction event is believed to have been caused by a devastating change in the global climate.

\subsection{Medieval Bee Mortalities}

In medieval Europe, there was a mention of "bee mortality" in Ireland in 951, according to the Annals of Ulster. Citing the same source, Fleming [18] noted "high mortality among humans, cattle and bees" again in Ireland in 992. In the same year, the extinction of bees was preceded by a long and severe winter, and drought in the summer, combined with an attack by fungal "diseases or turf" (namely, ergot, Claviceps purpurea (Fr.) Tul. 1853) on cereals. The ergot sclerotium contains high concentrations (up to $2 \%$ of dry mass) of the alkaloid ergotamine, which accumulates in the so-called sugary honeydew, which attracts bees. The result was a mass famine and an epidemic of ergotism in France in the same year. The harsh winter and dry summer preceded the "unprecedented pestilence and devastation of the bees" affecting all of Bavaria in 1035. The unusual cold in the summer of that year eliminated the production of corn and fruit (Annals of Ulster). 
Even these historical records from medieval Europe point to a clear causality: bad weather resulting in decreased nectar production, which, in turn, had a negative impact on colony productivity.

The earliest recorded shipment of bees to the New World (North America) took place from England in 1621. By 1650, nearly all farms in New England are reported to have had one or two colonies of bees, but there is evidence that the number of bees managed by American colonists declined after 1670, 50 years after the honey bee was introduced from Europe to North America. According to Pellett [19], the most likely cause was associated with an unknown infectious disease.

\subsection{Other Unexplained Evidence for Bee Mortality}

Many of the bee epidemics recorded in detail in the past remain unexplained. For example, in 1903, 2000 colonies were lost to an unknown "disappearing disease" in the Cache Valley of Utah [20]. Significantly, however, the previous winter had been hard and the spring cold. In 1995-1996, beekeepers in Pennsylvania lost $53 \%$ of their colonies to no specifically identifiable cause [21]. One of the most famous epidemics occurred on the Isle of Wight, a small island off the south coast of England, when three separate epidemics between 1905 and 1919 wiped out 90\% of the island's bees [22]. In this case, pathogenic factors, such as the tracheal mite Acarapis woodi and the microsporidia Nosema apis, were involved. Thereafter, after long and lengthy research over the years it is suggested that the disease had been due to a combination of factors, in particular, infection by Chronic Bee Paralysis Virus (completely unknown at the time), together with unfavorable climatic conditions that restricted the growth of plants and, hence, indirectly affected the foraging by bees because of the lack of flowers [23].

Although the number of managed beehives globally has increased by $45 \%$ since 1961, the proportion of bee-dependent pollinating crops has increased much more steeply-by 300\% [24]. In this regard, many beehives, especially in countries with industrialized, high-intensity agriculture, are raised as mobile units for the purpose of pollination of crops, not for the production of bee honey and other products [25]. Insufficient attention has been paid to the potential negative effect of long-distance transport of beehives and the related stress for bees [26,27].

\section{Colony Collapse Disorder Syndrome}

Many studies link the death of bee colonies to the popular Colony Collapse Disorder symptom/syndrome (CCD). As the name suggests, a typical characteristic of this pathological phenomenon, is the total absence or the presence of very few adult (imagined) bees in the hive, in the presence of live brood (eggs, larvae, pre-pupae, and pupae) and an alive bee queen. A common feature is that worker bees leave the hive and do not return $[28,29]$. In fact, there is no factual evidence of the death of individuals. No dead bodies are found inside or in front of the affected hive, which is a characteristic sign of acute poisoning [30]. In addition, there is no indication of an invasion of the hive by other insects, such as wasps or hornets. Visual inspection shows that live individuals in the hive, both imagined and brood, are usually infested by the ectoparasitic mite-Varroa destructor [31]. Other pests found in all bee colonies affected by the syndrome are intracellular, intestinal parasites (microsporidia), mainly Nosema ceranae, and other representatives of the same genus [32]. Other unspecific signs indicating that the bee colonies are in crisis but not necessarily dictated by CCD include the shortened period (from approximately 25 to 5 days) during which young bees take care of larvae and pupae before becoming workers that produce wax; significantly delayed attacks by hive pests, colony includes mostly young adult bees, etc. In its classic form, the syndrome appears to be localized only in the United States and, in some cases, in Europe [33].

\section{What Actually Leads to Honey Bee Decline?}

Widespread notions, including such among the academic community, relate the main problem-the decrease in the number of bee colonies and any other form of bee losses-mainly or exclusively, to the aforementioned pathological phenomenon of CCD. However, scientists and experts involved in researching the problem consider two forms of honey bee losses: 
1. Annual (most frequent) - as a result of unsuccessful wintering caused by biotic factors (such as infections and parasites), acute intoxication, and a number of other causes, which are subject of the discussion in this review [34]

2. Multi-annual—permanent reduction in the number of bee colonies in separate, specific regions.

For example, it is known that from the mid-1980s until now, the number of bee colonies in Europe has decreased by $25 \%$ and in the United States by $50-60 \%$ [35]. At the same time, despite sporadic local extinction, the number of bee colonies globally has increased by about $45 \%$ over the last 50 years and more specifically since 1961 [24,35]. The latter seems hopeful, but these data must be interpreted with care. Usually, beekeepers compensate for the loss of one hive by splitting it into two. This results in the "weakening" of the two new bee colonies, and the long-term effect of repeated application of this practice has not been fully studied. Very often, there is a lack of objectively collected information on the status of the honey bee in individual countries, on population changes over the years, and by region. For example, in Austria and Czechia, colony losses during winter were fluctuating from year to year, with strong regional differences. It has been observed that winter losses related to queen problems, differences in population dynamics, and treatment against the Varroa mite, differences in the number of beekeepers and colonies, etc. [36]. Generally, in the 20th century in Europe, two periods were distinguished according to the prevailing trend: an increase in the total number of bee colonies in 1965-1985, and a decrease in the number of beehives in 1986-2005 [4]. The number of beekeepers, both professionally engaged and those for whom beekeeping is a hobby (holdings with up to 50 bee colonies), has also been decreasing in Europe. The changes recorded between 2000 and 2010 show an increase in the total number of hives in Europe from 15 million in 2000 to 16.4 million in 2007, a decrease in 2008-2009, and again, some increase towards the end of the period-2010, to about 15.8 million hives [37]. In comparison, in 2010, the registered bee colonies in Bulgaria were over 613,000 [35]. While, in 2006, bee colonies in the country amounted to 671,674, in 2007 to 718,822, in the following years, their number kept steadily decreasing, and in 2012 it reached 529,117-a reduction from $21 \%$ to $26.4 \%$. During this period, the number of holdings engaged in beekeeping (beekeepers) also decreased from 31,026 in 2008 to 19,238 in $2012-a$ a 40 reduction.

\section{Factors Affecting the Health of Honey Bees}

There are five stressors of global importance that are thought to be relevant to the reducing number of bee colonies in different parts of the world. These are the anthropogenic driven worldwide spread of pathogenic organisms and pest beetles (Aethina tumida), climate change and adverse climatic conditions, landscape changes with limitation of natural habitats, intensification of agricultural production (including the use of fertilizers and pesticides), and invasion of new non-native species [38].

\subsection{Biotic Factors}

A total of 29 diseases and pests are known to be the cause of the annual loss of bee colonies almost everywhere in the world [35]. Among the causative agents and pests in the honey bee colonies are Varro mite (Varroa destructor), microsporidia (Nosem apis; N. ceranae, the more virulent one); fungi such as Ascophaera apis; bacteria (Paenibacillus larvae, Melissococcus plutonius), amoebae (Malpighamoeba mellificae), septicemia and spiroplasm, small hive beetles (Aethina tumida), wax moths (Pyralidae), and others $[3,38]$.

The parasitic mite Varroa destructor was introduced into Europe (possible in the 1950s) [39], and North America (first detected in 1987s), [40], making it a nearly ubiquitous honey bee pest [41]. An exception is Australia, as well as some isolated islands and probably individual Central African countries where the parasite has not yet been identified [4]. This mite is responsible for significant annual losses of bee colonies in Canada and a number of European countries [35]. In regions where $V$. destructor is not a major problem, beekeeping is negligible or does not occur at all [42]. A number of authors have identified this species as the most probable cause of bee populations extinction in Europe, USA, and Canada [31,35,43-45]. In addition to being direct pests, mites are a vector of various 
viral diseases in parasitized bees [28,42]. Examples of the latter include the Deformed Wings Virus, the Acute Bee Paralysis Virus, the Israeli Acute Paralysis Virus, and the Kashmir Bee Virus-all directly related to the empty hive syndrome [46-48].

Microsporidian infections with Nosema spp.-N. ceranae and N. apis-lead to acute diarrhea in bees during the winter-spring season or to a latent infection $[49,50]$. There have been cases where infections with $N$. ceranae cause symptoms identical to the decline of bee colonies [51]), but the relationship between the two pathological phenomena are poorly understood [35].

The small hive beetle, Aethina tumida, adversely affects all aspects of beekeeping, including queen rearing, honey production and processing, and pollination operations. In honey bee colonies, they feed on pollen, honey, and occasionally brood. The damage associated with an Aethina tumida infestation is caused by the beetle larval stage; adults have little negative impact on a colony besides distracting worker bees from their normal hive duties [52].

The Greater wax moth (Galleria mellonella) is another opportunistic pest found in honey beehives, and cause significant damage to stored combs [53]. The damage caused by G. mellonella larvae is severe in tropical and sub-tropical regions and is believed to be one of the contributing factors to the decline in both feral and wild honeybee populations.

While in Europe, biotic factors, mainly infections and parasites of the hives, are given great importance; most of the loss of bee colonies in the United States is attributed to adverse weather factors, starvation, loss of the bee queen or stress from transporting hives over long distances, and infection (mainly viruses, bacteria, and fungi) that may contribute to CCD syndrome $[27,29,54,55]$. However, the studies cited here do not take into account the prior health status of beehives killed in case of transport stress [35].

\subsection{Abiotic Factors}

\subsubsection{Climate Change}

In order to assess the potential impact of a future climate change on populations of cultured bees and other pollinators in the long term, the effects of Earth's climate changes over the last millennia should be analyzed. There have been three cooling periods and three warming periods over the last 3000 years [56,57]. For example, the first global cooling took place in the Early Middle Ages; the so-called "Dark Ages" (Procopius, History of the Wars) may have resulted from a powerful volcanic eruption, probably in Indonesia, which saturated the atmosphere with dust and toxic gases. It was followed by a global warming between the 10th and the 14th centuries, and consequently a new cold period, known as the "Little Ice Age", which continued until the mid 19th century [58,59]. During these alternating periods, which had somewhat contrasting effects on agriculture and crop zoning as well as on the flora and fauna of the moderate latitude, bees did not disappear completely, even though they had undergone some population fluctuations, as can be seen from the historical documents cited above. The current warming, which has been claimed to have been around since 1850, should not have had an adverse effect on insects, including those involved in plant pollination. Climate change can impact on honey bees at different levels. It can have a direct influence on honey bee behavior and physiology [60]. It can alter the quality of the floral environment and increase or reduce colony harvesting capacity and development. It can define new honey bee distribution ranges and give rise to new competitive relationships among species and races, as well as among their parasites and pathogens [60]. Beekeepers will also be obliged to change their apiculture methods. They will favor moving their hives to new foraging areas and importing foreign races to test their value in the new environments.

Another study has investigated climate's influence on honey bee winter mortality rates across Austria [61]. The results have shown statistical correlations between monthly climate variables and winter mortality rates indicated that warmer and drier weather conditions in the preceding year were accompanied by increased winter mortality. 


\subsubsection{Unfavorable Weather Conditions}

In addition to historical data, a number of contemporary authors [62-64] also attach great importance to unfavorable weather conditions and dramatic changes in weather as a factor in the reduction of bee colonies. Long periods of cold and rainy or hot and dry weather are associated with the sudden and unexplained disappearance of bees and the emptying of hives [28]. A probable cause is the prolonged lack of nectar and pollen (foraging), which inevitably leads to the collapse of bee colonies. The cold spring of 2013 in the USA led to a later development of hives, thus shortening the period for development of $V$. destructor. The smaller number of developed generations of the parasite, as well as the subsequent warm period suitable for active foraging time, contributed to a significantly lower loss of bee colonies in 2013 compared to the following 2014 [65,66]. In the same connection, but in the opposite direction, there also is the suggestion that chronic hive intoxication due to the treatment with thiomethoxan (a neonicotinoid), may delay the development of the larvae and endangering the existence of the bee colony [67].

Between 2006 and 2011, about 32\% of hives in the USA kept dying every year due to unsuccessful wintering [3]. The same was valid for the winter of 2012-2013, when $31 \%$ of the hives perished. According to beekeepers, a symptomatic pattern similar to the "empty hive" can be observed in years when the temperature rises early in the spring, often before the snow melts. During this period of the year, bees need more water, including for breeding offspring. On the other hand, the effects of low temperatures and wind can also hinder the return to the hive, resulting in mass losses. To avoid this particular mechanism of emptying the hive, beekeepers recommend providing warmed liquids with added sugar or honey.

\section{Pesticides as a Factor in the Deterioration of the Health Status of Bees and Bee Colonies}

Bees are exposed to pesticides-through the chemical means used by beekeepers to control diseases and pests in or around hives. The contrasting results with clothianidin treated seeds were reported because this pesticide primarily influenced arthropod communities during the four weeks following planting, with disruptions to major natural enemy taxa, but communities showed trends toward recovery at the later corn stages. [68,69]. Rundlof, et al.'s [68] study took place in spring and reported negative effects on bees, whereas Sterk, et al.'s [69] study took place in autumn and reported no significant effects. Bees come in contact with pesticides when drifting (driven by air currents) through spray drift or dusting from an applied product, for example, in proximity to recently sprayed growing plants, when soil is treated or when treated seed is used for sowing [70,71]. Oral intoxication is also possible when visiting flowering weed vegetation recently treated with pesticide or when ingesting contaminated food and water-pollen, nectar, guttation drops, and honeydew on treated plants, etc. [72-74].

Sublethal doses of pesticide products, or even some pesticides considered to be completely safe, can lead to severe losses or endanger the existence of the bee colonies [75]. According to some observations, if during the treatment of apiaries is adjacent to the other apiaries, bees fly through the spray drift of the pesticide, and then they absorb with their bodies an odor different from the one specific to the hive [76,77]. Impacted individuals are, thus, not recognized by the bees guarding the bee colony, and, as a result of which, they are not allowed into the hive or are killed as invaders [78-80]. This circumstance further necessitates the strict application of the requirement to broadcast warnings locally before carrying out all chemical treatments-spraying, sowing of treated seeds, etc. It is obvious that the phenophase of the target culture-flowering or other-is irrelevant in this case.

\subsection{Effect of Pesticides (Other than Neonicotinoids) on Bee Health}

Exposure of bees to sublethal doses of pesticides occurs not only with systemic products (most commonly, aqueous solutions applied to vegetative plants) but also with non-systemics, such as pyrethroids and organophosphates, which can reduce the lifespan of individuals $[75,76]$. Recent 
studies have shown that low levels of intoxication-oral or contact, with active substances other than neonicotinoids-can weaken the immune system of exposed individuals, impair their ability to learn by monitoring and communicating with other bees, thus leading to memory loss and a change in their eating behavior and ability to distinguish flavors [72-84].

Increased levels of chlorothalonil fungicide have been detected in bee pollen in hives where high mortality has been observed. However, artificial feeding of larvae and adults with a product containing the same pollen does not cause an increase in mortality among individuals during an experiment [85]. The bees are more susceptible to most insecticides but particularly to fipronil (the most deadly to bees), most neonicotinoids and pyrethroids, and some organophosphates. According to Smith et al. [35], the greatest challenge for researchers is to extrapolate data on the effects of pesticide action on bees obtained at the individual experimentation level to the whole bee colony. Studies on their effects on bees are approved by OECD (Organisation for Economic Co-operation and Development) toxicity test guidelines. By DNA microarray analysis of transcribed products from the intestinal tract of beehives in decay, Johnson, et al. [86] found the presence of unusual RNA fragments that are thought to result from infection with one or more viruses. The authors did not find increased expression of genes related to the body's response to pesticide intoxication. For at least two decades, individual researchers have focused on exploring the mechanisms of bee detoxification and, in particular, on the role of the P450 gene, which encodes the ability of bees to metabolize toxic compounds that have fallen into the hive $[87,88]$. It has been suggested that there is a risk of honey bee survival if honey bees collect and drink water from water puddles in crops treated with neonicotinoid insecticides [89]. Also, honey bees and other native pollinators are threatened by cumulative exposure to these insecticides from residues in pollen, nectar, and water [89].

\subsection{Neonicotinoid Insecticides}

Neonicotinoids are synthetic alkaloid insecticides, analogs of natural nicotine. In treated plants, they systematically propagate acropetally (ascending xylem). They are placed in the group of neurotoxic insecticides. Neonicotinoids bind to the nicotinic receptors located in the postsynaptic membrane of neurons to cause their activation because they are agonists of the receptor [90,91]. Indeed, they are selective because they tend to bind preferentially to one of the subunits $(\alpha 4 \beta 2)$ that make up the receptor, which happens to be more common in insects than in vertebrates. Neonicotinoids are applied in different forms-spraying of aboveground parts of plants, treatment of seeds, and application directly to the soil in a wide range of crops. Two groups of neonicotinoids are known to date: cyano-substituted (acetamiprid and thiacloprid) and nitro-substituted (imidacloprid, thiamethoxam, clothianidin, nitenpyram, and dinotefuran). Furthermore, it has been demonstrated that the three main neonicotinoids used in agriculture the world over, namely imidacloprid, thiamethoxam, and clothianidin, pose the highest risks to bees among all other pesticides [92,93]. The difference is in the chemical formula determining the different toxicity of the two groups of active substances against bees [92,93]. For example, cyano-substituted neonicotinoids, like thiacloprid and acetamiprid, increase their toxicity to bees by 500 and 100 times in the presence of azole fungicides.

From the dawn of this millennium, a broad debate has started within the scientific community, giving rise to a number of research programs on the negative impact of neonicotinoid pesticides on pollinating insects, in particular, the managed honey bee or otherwise exploited wild bee colonies [3,38,94,95].

Neonicotinoid insecticides enter the body of honey bees, bumble bees, or other pollinators when insects feed on nectar and pollen from treated plants [96]. Krupke, et al. [97] considered different routes of contamination of beehives with neonicotinoids but focused primarily on the use of coated seeds and granules, which contaminate the soil. Yang, et al. [98] found a negative effect of sublethal doses of imidacloprid on honey bee behavior. Feeding individuals with sugar syrup containing $50 \mu \mathrm{g} / \mathrm{L}$ has shown to prolong the time interval between two visits to the feeding site $[99,100]$. The use of $1250 \mu \mathrm{g} / \mathrm{L}$ imidacloprid syrup for food results in significant behavioral changes, with some individuals failing 
to return to their normal foraging habits, while for others, the time required to return to the hive is extended significantly $[99,100]$. Increased mortality as a result of disorientation and inability to find the way back to the hive has been observed in bees intoxicated with thiamethoxam [101,102]. Bee colonies exposed to chronic effects of clothianidin and thiamethoxam experience significant, detrimental short and long-term impacts on colony performance and queen fate, which suggests that neonicotinoids may contribute to colony weakening in a complex manner [46]. The same authors have found that losses in individual bee colonies are determined by different levels of genetically determined resistance of bees to intoxication [46].

Some comparisons are needed with regard to the usage of neonicotinoides in different countries. In Australia, $80 \%-90 \%$ of beekeepers avoid agricultural fields and place their hives in forests to get the best harvest of honey. Therefore, their exposure to pesticides is minimal, unlike what occurs in the USA, Europe, Japan, or China. Australian beekeepers also know that whenever they take their hives for pollination of almonds, they lose hives, and when their bees forage on neonicotinoid-treated canola fields, they get sick and lose more hives the following winter. Moreover, Australia has been fortunate, to date, to avoid any incursion of Varroa, which presents a major threat to the health of honey bees [103]. For this reason, Australia exports bee products, bee queens, and whole hives for pollinating crops. On the contrary, imports are strictly prohibited, and quarantine measures are mandatory [104]. Because the use of neonicotinoid insecticides have proven to have particularly harmful effects on the environment (especially pollinators, and that includes bees above all). France becomes the first country in Europa that banned the use of five neonicotinoids completely.

\section{Interactive and Cumulative Effects: Action of Biotic and Abiotic Stressors}

With regard to the causes of death of bee colonies, opinions are most often polarized, claiming that one or another individual stress factor is the main, if not the sole, cause of the phenomenon. Recently, it has become increasingly accepted that the combined action of two or more adverse factors of different nature increases the risk of colony collapse. It has been hypothesized that the poor health status of bees is the result of individual or combined action of various factors such as stress due to poor nutrition, fasting and "monocultural" diet, abrupt meteorological changes, reduced genetic diversity in honey bee populations, etc., not excluding additional, chronic pesticide intoxication [30,39]. Too little is known about the immune response in bees at the individual and colony level. However, as social insects, bees can rely on a collective immune response to protect the colony as a whole [105]. Recently, balanced feeding of pollen and propolis has been found to be able to activate detoxifying enzymes in the individual bee [106]. It is also considered that experimental data on the effects on the protective capabilities of an individual cannot be automatically extrapolated to the entire colony in actual field experiments [35].

Recent studies have shown that interactions between pesticides and pathogens lead to deterioration in the health status of bee colonies $[74,107,108]$. Exposure to neonicotinoid pesticides increases the sensitivity of bees to the intestinal parasite N. ceranae [109]. Imidacloprid is able to synergistically increase the level of infection with Nosema spp. [73], as well as mortality [107], when both stressors are present simultaneously in the hive. Similarly, Aufauvre, et al. [74] found higher mortality from fipronil intoxication and infection with $N$. ceranae combined than when the two agents acted in isolation.

The interaction between stressors is not limited to pesticides and pathogens. Very often, the malnutrition of beehives is highlighted as a factor increasing the losses caused by bee parasites. For example, the parasite Crithidia spp. causes less mortality if wild bees have a complete food source [110]. Goulson, et al. [30] suggest that nutritional stress influences LD50 values (lethal dose, 50\%) for individual bee toxic compounds. This is evidenced by the varying values of LD50 for pesticides in separate, independent studies [75].

Goulson, et al. [30], note that the individual factors that have a negative effect on bee health do not act in isolation. Obviously, all types of bees are subjected to different stress factors at the same time and with an accumulating effect over time. In doing so, each individual factor reduces the ability of bees to 
overcome the negative effects of the action of other stressors. The mortality of bees and bee colonies is likely to be lower if the parasite-infested hive is not further exposed to sublethal doses of toxic substances, incl. antibiotics and acaricides used in beekeeping. Moreover, the pesticides in agriculture and/or bees are not starved or subjected to a monotonous diet, often as a result of adverse weather conditions, such as prolonged drought or low temperatures. The conclusion is that complex causes require the search for complex solutions to the problem. The strategy should be aimed at reducing the general and individual stress from the action of various adverse factors by radically changing the environment in which the bees live and in which they perform their functions.

\section{Some Examples for Solving the Problem of Honey Bee Population Decline}

\subsection{The Hindu Kush Lessons}

The prospect of life without bees and other pollinators was demonstrated in the Maoxian region, Sichuan province, Southwestern China, part of the Hindu Kush Mountain, where bees, both wild and honey-bearing (European and Eastern,) disappeared more than 20 years ago [111]. In the early 1990s, local, until then self-sufficient, farmers, largely catering to their own needs, set out to create market-oriented apple and pear plantations. Both fruits are self-sterile, which requires pollinating the flowers with pollen from other, genetically distant species (varieties) of the species. With the intensification of production and the desire to market better looking fruits, the use of pesticides, and in particular, insecticides, increased. The mistaken perception that the cause of the lower pollination is insect pests attacking the flowers has led to an even more intensive use of insecticides. Natural habitats-alternative sources of nectar for bees-mainly forests and natural vegetation, have been replaced by new, industrial plantations. This effectively reduced the bee feeding period to 14 days a year. The second big problem in the region was the lack of managed honey bees and other pollinating insects. As of 1999, the problem covered neighboring Hindu Kush areas-territories of India, Pakistan, and Nepal [111,112]. The case is unique in that, in order to survive, local farmers were forced to switch to manual pollination of fruit tree flowers [111]. In India, Nepal, and Pakistan, the problem was solved with the restoration of native vegetation, providing habitats and food sources for bees, appropriate management of the natural pollination process, and training of farming colonies. Thus, bee populations were restored, and after 2011, manual pollination has rarely been practiced.

What conclusions can be drawn from the Hindu Kush experience? The main problem is, however, the use of certain pesticides in agriculture, even as recommended on the labels [113]. Another problem is the approval of certain compounds and formulations for use in some crops because they pose more risks to bees and the environment than those estimated by the regulatory authorities. The latter is due to authorities using insufficient or inappropriate information and out of date methods [114]. Improper use of pesticides in agriculture is part of the problem, but it is not the only cause of death for honey and other bee species. Refusing to use pesticides, even if possible and as a sole measure, would not be a solution to the problem. Restoring and preserving the natural habitats of pollinators today can ensure the diversity of our table tomorrow [115].

\subsection{The Experience of North America}

With the decrease in the number of bee colonies in the United States by more than $50 \%$ as a result of the introduction of parasitic mites, heavy pesticide use, and industrialized plantations, crossbreeds between the European, A. mellifera and the African honey bee, Apis mellifera scutellata Lepeletier have been introduced [116]. New, hybrid forms show increased resistance to parasites, infectious diseases, and some pesticides $[117,118]$. They also find successful application in the agricultural practices of Latin American countries, such as Brazil, where they have replaced the European bee and have even been rated as better pollinators than the European one [119]. The problems associated with the use of these: the so-called "Africanized" bees or "killer bees" include smaller numbers of workers in one colony, shorter flight and perimeter of feeding around the colonies, and high mortality when moving to 
a new foraging site. In addition, Africanized bees are extremely aggressive. They are now considered inapplicable to the USA because of the mobile nature of bee pollination used there for many crops [117]. The measures taken in the country are aimed at the use of less intensive forms of agriculture related to reducing the dependence of agriculture on the use of pesticides. The conservation of weeds and other vegetation around arable land where bees would find additional foraging for a longer period is promoted. Research in this regard shows that structural changes in the landscape distribution of crops with the conservation and/or introduction of wild plant species increase the species diversity of bees and pollinating butterflies [120].

\section{Concluding Remarks}

The recent concerns in some regions over an increase in colony losses have prompted investment in more coordinated monitoring of bees and research into how pests and diseases, bee diversity, beekeeping practices, and their foraging environment is affecting bee vitality. The global picture shows that regions with established honey bee parasitic Varroa mite populations ( $V$. destructor) have consistently higher colony losses. The active role of $V$. destructor as a vector of bee viruses is emerging as a significant factor in the losses of honey bee colonies seen globally. In addition, land management and environmental conditions affect the availability and quality of food sources and also affect conditions in the hive, and effective management of bee colonies under changing situations is dependent on beekeeping practices and bee selection/breeding.

The potential pesticide risk maps could aid in the prevention of honeybee colony losses. The maps could help identify regions with relatively high pesticide pressure in a species-specific manner, enabling conservation actions on a local scale. This could result in a lower local pesticide pressure for the bee species in question while minimizing economic damages since enforced pesticide regulations could be tailored to local high-risk areas. Such actions could help restore threatened bee species and lower honey bee colony losses, which would benefit pollinator dependent farmers and plant species by the increase of pollination services.

Author Contributions: All authors contributed equally to writing this review.

Funding: This work was funded by the National Scientific Fund of the Bulgarian Ministry of Education and Science (grant numbers 06/10 17/12/2016). The funders had no role in study design, data collection and analysis, decision to publish, or preparation of the manuscript.

Conflicts of Interest: The authors declare no conflict of interest.

\section{References}

1. Crane, E. Recent research on the world history of beekeeping. Bee World 1999, 80, 174-186. [CrossRef]

2. Roffet-Salque, M.; Regert, M.; Evershed, R.P.; Outram, A.K.; Cramp, L.J.; Decavallas, O.; Dunne, J.; Gerbault, P.; Mileto, S.; Mirabaud, S.; et al. Widespread exploitation of the honeybee by early Neolithic famers. Nature 2015, 527, 226-230. [CrossRef] [PubMed]

3. Bee Health: The Role of Pesticides; Reports for Congress. Available online: https://www.fas.org/sgp/crs/ misc/R42855.pdf (accessed on 11 December 2012).

4. Potts, S.G.; Biesmeijer, J.C.; Kremen, C.; Neumann, P.; Schweiger, O.; Kunin, W.E. Global pollinator declines: Trends, impacts and drivers. Trends Ecol. Evol. 2010, 25, 345-353. [CrossRef] [PubMed]

5. Gill, R.J.; Ramos-Rodriguez, O.; Raine, N.E. Combined pesticide exposure severely affects individual- and colony-level traits in bees. Nature 2012, 491, 105-108. [CrossRef] [PubMed]

6. Ollerton, J.; Winfree, R.; Tarrant, S. How many flowering plants are pollinated by animals? Oikos 2011, 120, 321-326. [CrossRef]

7. Geslin, B.; Gauzens, B.; Baude, M.; Dajoz, I.; Fontaine, C.; Henry, M.; Ropars, L.; Rollin, O.; Thébault, E.; Vereecken, N.J. Massively introduced managed species and their consequences for plant-pollinator interactions. Adv. Ecol. Res. 2017, 57, 147-199. 
8. Hermansen, T.D.; Britton, D.R.; Ayre, D.J.; Minchinton, T.E. Identifying the real pollinators? Exotic honey bees are the dominant flower visitors and only effective pollinators of Avicennia marina in Australian temperate mangroves. Estuar. Coasts 2014, 37, 621-635. [CrossRef]

9. Thompson, C.E.; Biesmeijer, J.C.; Allnutt, T.R.; Pietravalle, S.; Budge, G.E. Parasite pressures on feral honey bees (Apis mellifera sp.). PLoS ONE 2014, 9, e105164. [CrossRef]

10. Giannini, T.C.; Garibaldi, L.A.; Acosta, A.L.; Silva, J.S.; Maia, K.P.; Saraiva, A.M.; Guimaraes, P.R.; Kleinert, A.M.P. Native and non-native supergeneralist bee species have different effects on plant-bee networks. PLoS ONE 2015, 10, e0137198. [CrossRef]

11. Abe, T.; Wada, K.; Kato, Y.; Makino, S.; Okochi, I. Alien pollinator promotes invasive mutualism in an insular pollination system. Biol. Invasions 2011, 13, 957-967. [CrossRef]

12. Gross, C.L.; Mackay, D. Honeybees reduce fitness in the pioneer shrub Melastoma affine (Melastomataceae). Biol. Conserv. 1998, 86, 169-178. [CrossRef]

13. Wratten, S.D.; Gillespie, M.; Decourtye, A.; Mader, E.; Desneux, N. Pollinator habitat enhancement: Benefits to other ecosystem services. Agric. Ecosyst. Environ. 2012, 159, 112-122. [CrossRef]

14. Rader, R.; Bartomeus, I.; Garibaldi, L.A.; Garratt, M.P.; Howlett, B.G.; Winfree, R.; Cunningham, S.A.; Mayfield, M.M.; Arthur, A.D.; Andersson, G.K.; et al. Non-bee insects are important contributors to global crop pollination. Proc. Natl. Acad. Sci. USA 2016, 113, 146-151. [CrossRef] [PubMed]

15. Minteer, B.A.; Collins, J.P. Move it or lose it? The ecological ethics of relocating species under climate change. Ecol. Appl. 2010, 20, 1801-1804. [CrossRef] [PubMed]

16. UNEP Emerging Issues: Global Honey Bee Colony Disorder and Other Threats to Insect Pollinators. Available online: http://www.unep.org/dewa/Portals/67/pdf/Global_Bee_Colony_Disorder_and_Threats_ insect_pollinators.pdf (accessed on 10 March 2011).

17. Rehan, S.M.; Leys, R.; Schwarz, M.P. First Evidence for a Massive Extinction Event Affecting Bees Close to the K-T Boundary. PLOS ONE 2013, 8, e76683. [CrossRef]

18. Fleming, G. Animal Plagues: Their History, Nature, and Prevention; Chapman and Hall: London, UK, 1871; p. 548.

19. Pellett, F.C. History of American Beekeeping; Collegiate Press: Ames, IA, USA, 1938; p. 303.

20. Critchlow, B.P. Gleanings in Bee Culture. Bee Cult. Mag. 1904, 32, 692.

21. Finley, J.; Camazine, S.; Frazier, M. The epidemic of honey bee colony losses during the 1995-1996 season. Am. Bee J. 1996, 136, 805-808.

22. Bailey, L. The 'Isle of Wight Disease': The Origin and Significance of the Myth. Bee World 1964, 45, 32-37. [CrossRef]

23. Bailey, L. The Isle of Wight Disease; Central Association of Bee-Keepers: Poole, UK, 2002; p. 11.

24. Aizen, M.A.; Harder, L.D. The global stock of domesticated honey bees is growing slower than agricultural demand for pollination. Curr. Biol. 2009, 19, 915-918. [CrossRef]

25. Sumner, D.A.; Boriss, H. Bee-conomics and the leap in pollination fees. J. Agric. Resour. Econ. 2006, 9, 9-11.

26. Daberkow, S.; Korb, P.; Hoff, F. Structure of the US beekeeping industry: 1982-2002. J. Econ. Entomol. 2009, 102, 868-886. [CrossRef] [PubMed]

27. vanEngelsdorp, D.; Caron, D.; Hayes, J.; Underwood, R.; Henson, M.; Rennich, K.; Spleen, A.; Andree, M.; Snyder, R.; Lee, K.; et al. A national survey of managed honey bee 2010-2011 winter colony losses in the USA: Results from the Bee Informed Partnership. J. Apic. Res. 2012, 51, 115-124. [CrossRef]

28. vanEngelsdorp, D.; Evans, J.D.; Saegerman, C.; Mullin, C.; Haubruge, E.; Nguyen, B.K.; Frazier, M.; Frazier, J.; Cox-Foster, D.; Chen, Y.P.; et al. Colony collapse disorder: A descriptive study. PLoS ONE 2009, 4, e6481. [CrossRef] [PubMed]

29. vanEngelsdorp, D.; Hayes, J.J.; Underwood, R.; Pettis, J.S. A survey of honey bee colony losses in the United States, fall 2008 to spring 2009. J. Apic. Res. 2010, 49, 7-14. [CrossRef]

30. Goulson, D.; Nicholls, E.; Botías, C.; Rotheray, E.L. Bee Declines Driven by Combined Stress from Parasites, Pesticides and Lack of Flowers. Science 2015, 347, 1255957. [CrossRef]

31. Le Conte, Y.; Ellis, M.; Ritter, W. Varroa mites and honey bee health: Can Varroa explain part of the colony losses? Apidologie 2010, 41, 353-363. [CrossRef]

32. Fries, I.; Martín-Hernández, R.; Meana, A.; García-Palencia, P.; Higes, M. Natural infections of Nosema ceranae in European honey bees. J. Apic. Res. 2006, 45, 230-233. [CrossRef] 
33. Ellis, J.D.; Evans, J.D.; Pettis, J. Colony losses, managed colony population decline, and Colony Collapse Disorder in the United States. J. Apic. Res. 2010, 49, 134-136. [CrossRef]

34. van der Zee, R.; Pisa, L.; Andonov, S.; Brodschneider, R.; Charriere, J.D.; Chlebo, R.; Coffey, M.F.; Crailsheim, K.; Dahle, B.; Gajda, A.; et al. Managed honey bee colony losses in Canada, China, Europe, Israel and Turkey, for the winters of 2008-9 and 2009-10. J. Apic. Res. 2012, 51, 91-114. [CrossRef]

35. Smith, K.M.; Loh, E.H.; Rostal, M.K.; Zambrana-Torrelio, C.M.; Mendiola, L.; Daszak, P. Pathogens, Pests, and Economics: Drivers of Honey Bee Colony Declines and Losses. EcoHealth 2014, 10, 434-445. [CrossRef]

36. Brodschneider, R.; Brus, J.; Danihlík, J. Comparison of apiculture and winter mortality of honey bee colonies (Apis mellifera) in Austria and Czechia. Agric. Ecosyst. Environ. 2019, 274, 24-32. [CrossRef]

37. Capri, E.; Marchis, A. Bee Health in Europe: Facts and Figures 2013. In Compendium of the Latest Information on Bee Health in Europe; OPERA Research Centre, Università Cattolica del Sacro Cuore: Milano, Italy, 2013; p. 64.

38. Potts, S.; Biesmeijer, K.; Bommarco, R.; Breeze, T.; Carvalheiro, L.; Franzen, M.; Gonzalez-Varo, J.P.; Holzschuh, A.; Kleijn, D.; Klein, A.-M.; et al. Status and trends of European pollinators. In Key Findings of the STEP Project; Pensoft Publishers: Sofia, Bulgaria, 2015; p. 72.

39. Bee Health: The Role of Pesticides; Congressional Research Service (CRS), Reports for Congress. Available online: https://www.fas.org/sgp/crs/misc/R43900.pdf (accessed on 17 February 2015).

40. Anderson, D.L.; Trueman, J.W.H. Varroa jacobsoni (Acari: Varroidae) is more than one species. Exp. Appl. Acarol. 2000, 24, 165-189. [CrossRef] [PubMed]

41. Sanford, M.T.; Demark, H.A.; Cromroy, H.L.; Cutts, L. Featured Creatures: Varroa mite. USA: University of Florida Institute of Food and Agricultural Science. 2007. Available online: http://creatures.ifas.ufl.edu/misc/ bees/Varroa_mite.htm (accessed on 5 November 2019).

42. Rosenkranz, P.; Aumeier, P.; Ziegelmann, B. Biology and control of Varroa destructor. J. Invertebr. Pathol. 2010, 103, S96-S119. [CrossRef] [PubMed]

43. Neumann, P.; Carreck, N.L. Honey bee colony losses. J. Apic. Res. 2010, 49, 1-6. [CrossRef]

44. Aston, D. Honey bee winter loss survey for England, 2007-8. J. Apic. Res. 2010, 49, 111-112. [CrossRef]

45. Gajger, I.T.; Tomljanovic, Z.; Petrinec, Z. Monitoring health status of Croatian honey bee colonies and possible reasons for winter losses. J. Apic. Res. 2010, 49, 107-108. [CrossRef]

46. Genersch, E.; Aubert, M. Emerging and re-emerging viruses of the honey bee (Apis mellifera L.). Vet. Res. 2010, 41, 54. [CrossRef]

47. Genersch, E.; von der Ohe, W.; Kaatz, H.; Schroeder, A.; Otten, C.; Buchler, R.; Berg, S.; Ritter, W.; Muhlen, W.; Gisder, S.; et al. The German bee monitoring project: A long term study to understand periodically high winter losses of honey bee colonies. Apidologie 2010, 41, 332-352. [CrossRef]

48. Martin, S.J.; Highfield, A.C.; Brettell, L.; Villalobos, E.M.; Budge, G.E.; Powell, M.; Nikaido, S.; Schroeder, D.C. Global honey bee viral landscape altered by a parasitic mite. Science 2012, 336, 1304-1306. [CrossRef]

49. Paxton, R.J. Does infection by Nosema ceranae cause "Colony Collapse Disorder" in honey bees (Apis mellifera)? J. Apic. Res. 2010, 49, 80-84. [CrossRef]

50. Kaplan, J.K. Colony Collapse Disorder: An Incomplete Puzzle, Agricultural Research (USDA publication). 2012. Available online: http://www.ars.usda.gov/is/AR/archive/jul12/colony0712.htm (accessed on 5 November 2019).

51. Higes, M.; Garcıa-Palencia, P.; Martın-Hernandez, R.; Meana, A. Experimental infection of Apis mellifera honeybees with Nosema ceranae (Microsporidia). J. Invertebr. Pathol. 2007, 94, 211-217. [CrossRef] [PubMed]

52. Ellis, J.D.; Spiewok, S.; Delaplane, K.S.; Buchholz, S.; Neumann, P.; Tedders, W.L. Susceptibility of Aethina tumida (Coleoptera: Nitidulidae) larvae and pupae to entomopathogenic nematodes. J. Econ. Entomol. 2010, 103, 1-9. [CrossRef] [PubMed]

53. Kwadha, C.A.; Ongamo, G.O.; Ndegwa, P.N.; Raina, S.K.; Fombong, A.T. The Biology and Control of the Greater Wax Moth, Galleria mellonella. Insects 2017, 8, 61. [CrossRef] [PubMed]

54. vanEngelsdorp, D.; Hayes, J.; Underwood, R.M.; Caron, D.; Pettis, J. A survey of managed honey bee colony losses in the USA, fall 2009 to winter 2010. J. Apic. Res. 2011, 50, 1-10. [CrossRef]

55. Cox-Foster, D.L.; Conlan, S.; Holmes, E.C.; Palacios, G.; Evans, J.D.; Moran, N.A.; Quan, P.L.; Briese, T.; Hornig, M.; Geiser, D.M.; et al. A metagenomic survey of microbes in honey bee colony collapse disorder. Science 2007, 318, 283-287. [CrossRef]

56. Broecker, W.S. Was the medieval warm period global? Science 2001, 291, 1497-1499. [CrossRef] 
57. Andrew, J.T.; Norman, D.Y.; Keller, B.; Girard, R.; Heneberry, J.; Gunn, J.M.; Hamilton, D.P.; Taylor, P.A. Cooling lakes while the world warms: Effects of forest regrowth and increased dissolved organic matter on the thermal regime of a temperate, urban lake. Limnol. Oceanogr. 2008, 53, 404-410. [CrossRef]

58. Matthews, J.A.; Briffa, K.R. The 'Little Ice Age': Re-evaluation of an evolving concept. Geogr. Ann. A 2005, 87, 17-36. [CrossRef]

59. Mann, M.E.; Zhang, Z.; Rutherford, S.; Bradley, R.S.; Hughes, M.K.; Shindell, D.; Ammann, C.; Faluvegi, G.; $\mathrm{Ni}, \mathrm{F}$. Global signatures and dynamical origins of the Little Ice Age and Medieval Climate Anomaly. Science 2009, 326, 1256-1260. [CrossRef]

60. Le Conte, Y.; Navajas, M. Climate change: Impact on honey bee populations and diseases. Rev. Sci. Tech. OIE 2008, 27, 499-510.

61. Switanek, M.; Crailsheim, K.; Truhetz, H.; Brodschneider, R. Modelling seasonal effects of temperature and precipitation on honey bee winter mortality in a temperate climate. Sci. Total. Environ. 2017, 579, 1581-1587. [CrossRef] [PubMed]

62. Bartomeus, I.; Ascher, J.S.; Wagner, D.; Danforth, B.N.; Colla, S.; Kornbluth, S.; Winfree, R. Climate-associated phenological advances in bee pollinators and bee-pollinated plants. Proc. Natl. Acad. Sci. USA 2011, 108, 20645-20649. [CrossRef] [PubMed]

63. Guler, Y.; Dikmen, F. Potential bee pollinators of sweet cherry in inclement weather conditions. J. Entomol. Res. Soc. 2013, 15, 9-19.

64. Zagareanu, A.; Mardari, T.; Modvala, S. Stimulation of resistance of bee families during wintering. J. Anim. Sci. Biotechnol. 2013, 46, 268-271.

65. Brodschneider, R.; Gray, A.; Adjlane, N.; Ballis, A.; Brusbardis, V.; Charrière, J.-D.; Chlebo, R.; Coffey, M.F.; Dahle, B.; de Graaf, D.C.; et al. Multi-country loss rates of honey bee colonies during winter 2016/2017 from the COLOSS survey. J. Apic. Res. 2018, 57, 452-457. [CrossRef]

66. Gray, A.; Brodschneider, R.; Adjlane, N.; Ballis, A.; Brusbardis, V.; Charrière, J.-D.; Chlebo, R.; Coffey, M.F.; Cornelissen, B.; da Costa, C.A.; et al. Loss rates of honey bee colonies during winter 2017/18 in 36 countries participating in the COLOSS survey, including effects of forage sources. J. Apic. Res. 2019, 58, 479-485. [CrossRef]

67. Alburaki, M.; Boutin, S.; Mercier, P.L.; Loublier, Y.; Chagnon, M.; Derome, N. Neonicotinoid-coated Zea mays seeds indirectly affect honeybee performance and pathogen susceptibility in field trials. PLoS ONE 2015, 10, e0125790. [CrossRef]

68. Rundlöf, M.; Andersson, G.K.; Bommarco, R.; Fries, I.; Hederström, V.; Herbertsson, L.; Jonsson, O.; Klatt, B.K.; Pedersen, T.R.; Yourstone, J.; et al. Seed coating with a neonicotinoid insecticide negatively affects wild bees. Nature 2015, 521, 77. [CrossRef]

69. Sterk, G.; Peters, B.; Gao, Z.; Zumkier, U. Large-scale monitoring of effects of clothianidin-dressed OSR seeds on pollinating insects in Northern Germany: Effects on large earth bumble bees (Bombus terrestris). Ecotoxicology 2016, 25, 1666-1678. [CrossRef]

70. Nuyttens, D.; Devarrewaere, W.; Verboven, P.; Foque, D. Pesticide-laden dust emission and drift from treated seeds during seed drilling: A review. Pest. Manag. Sci. 2013, 69, 564-575. [CrossRef]

71. Sanchez-Bayo, F.; Goka, K. Pesticide residues and bees-a risk assessment. PLoS ONE 2014, 9, e94482. [CrossRef] [PubMed]

72. Alaux, C.; Ducloz, F.; Crauser, D.; Le Conte, Y. Diet effects on honeybee immunocompetence. Biol. Lett. 2010, 6, 562-565. [CrossRef] [PubMed]

73. Aufauvre, J.; Biron, D.G.; Vidau, C.; Fontbonne, R.; Roudel, M.; Diogon, M.; Vigues, B.; Belzunces, L.P.; Delbac, F.; Blot, N. Parasite-insecticide interactions: A case study of Nosema ceranae and fipronil synergy on honeybee. Sci. Rep. 2012, 2, 326. [CrossRef] [PubMed]

74. Pisa, L.W.; Amaral-Rogers, V.; Belzunces, L.P.; Bonmatin, J.M.; Downs, C.A.; Goulson, D.; Kreutzweiser, D.P.; Krupke, C.; Liess, M.; McField, M. Effects of neonicotinoids and fipronil on non-target invertebrates. Environ. Sci. Pollut. Res. Int. 2015, 22, 68-102. [CrossRef]

75. Meikle, W.G.; Corby-Harris, V.; Carroll, M.J.; Weiss, M.; Snyder, L.A.; Meador, C.A.D.; Beren, E.; Brown, N. Exposure to sublethal concentrations of methoxyfenozide disrupts honey bee colony activity and thermoregulation. PLoS ONE 2019, 14, e0204635. [CrossRef] 
76. Zawislak, J.; Adamczyk, J.; Johnson, D.R.; Lorenz, G.; Black, J.; Hornsby, Q.; Stewart, S.D.; Joshi, N. Comprehensive Survey of Area-Wide Agricultural Pesticide Use in Southern United States Row Crops and Potential Impact on Honey Bee Colonies. Insects 2019, 10, 280. [CrossRef]

77. Cook, S.C. Compound and Dose-Dependent Effects of Two Neonicotinoid Pesticides on Honey Bee (Apis mellifera) Metabolic Physiology. Insects 2019, 10, 18. [CrossRef]

78. Li, Z.; Li, M.; He, J.; Zhao, X.; Chaimanee, V.; Huang, W.F.; Nie, H.; Zhao, Y.; Su, S. Differential physiological effects of neonicotinoid insecticides on honey bees: A comparison between Apis mellifera and Apis cerana. Pestic. Biochem. Physiol 2017, 140, 1-8. [CrossRef]

79. Nasuti, C.; Fattoretti, P.; Carloni, M.; Fedeli, D.; Ubaldi, M.; Ciccocioppo, R.; Gabbianelli, R. Neonatal exposure to permethrin pesticide causes lifelong fear and spatial learning deficits and alters hippocampal morphology of synapses. J. Neurodev. Dis. 2014, 6, 7. [CrossRef]

80. Chrustek, A.; Hołyńska-Iwan, I.; Dziembowska, I.; Bogusiewicz, J.; Wróblewski, M.; Cwynar, A.; Olszewska-Słonina, D. Current Research on the Safety of Pyrethroids Used as Insecticides. Medicine 2018, 54, 61. [CrossRef]

81. Azpiazu, C.; Bosch, J.; Viñuela, E.; Medrzycki, P.; Teper, D.; Sgolastra, F. Chronic oral exposure to field-realistic pesticide combinations via pollen and nectar: Effects on feeding and thermal performance in a solitary bee. Sci. Rep. 2019, 9, 1-11. [CrossRef] [PubMed]

82. Gradish, A.E.; Van Der Steen, J.; Scott-Dupree, C.D.; Cabrera, A.R.; Cutler, G.C.; Goulson, D.; Klein, O.; Lehmann, D.M.; Lückmann, J.; O’Neill, B. Comparison of pesticide exposure in honey bees (Hymenoptera: Apidae) and bumble bees (Hymenoptera: Apidae): Implications for risk assessments. Environ. Entomol. 2018, 48, 12-21. [CrossRef] [PubMed]

83. Williamson, S.M.; Wright, G.A. Exposure to multiple cholinergic pesticides impairs olfactory learning and memory in honeybees. J. Exp. Biol. 2013, 216, 1799-1807. [CrossRef] [PubMed]

84. vanEngelsdorp, D.; Evans, J.D.; Donovall, L.; Mullin, C.; Frazier, M.; Frazier, J.; Tarpy, D.R.; Hayes, J.; Pettis, J.S. Entombed pollen: A new condition in honey bee colonies associated with increased risk of colony mortality. J. Invertebr. Pathol. 2009, 101, 147-149. [CrossRef] [PubMed]

85. Johnson, R.M. Managed pollinator CAP Coordinated Agricultural Project: A national research and extension initiative to reverse pollinator decline when varroacides interact. Am. Bee J. 2009, 149, 1157-1159.

86. Johnson, R.M.; Dahlgren, L.; Siegfried, B.D.; Ellis, M.D. Acaricide, fungicide and drug interactions in honey bees (Apis mellifera). PLoS ONE 2012, 8, e54092. [CrossRef]

87. Johnson, R.M. Honey Bee Toxicology. Ann. Rev. Entomol 2015, 60, 22.1-22.20. [CrossRef]

88. Samson-Robert, O.; Labrie, G.; Chagnon, M.; Fournier, V. Neonicotinoid-Contaminated Puddles of Water Represent a Risk of Intoxication for Honey Bees. PLoS ONE 2014, 9, e108443. [CrossRef]

89. Nauen, R.; Ebbinghaus-Kintscher, U.; Salgado, V.L.; Kaussmann, M. Thiamethoxam is a neonicotinoid precursor converted to clothianidin in insects and plants. Pestic. Biochem. Phys. 2003, 76, 55-69. [CrossRef]

90. Matsuda, K.; Buckingham, S.D.; Kleier, D.; Rauh, J.J.; Grauso, M.; Sattelle, D.B. Neonicotinoids: Insecticides acting on insect nicotinic acetylcholine receptors. Trends Pharmacol. Sci. 2001, 22, 573-580. [CrossRef]

91. Iwasa, T.; Motoyama, N.; Ambrose, J.T.; Roe, R.M. Mechanism for the differential toxicity of neonicotinoid insecticides in the honey bee, Apis mellifera. J. Crop. Protection. 2004, 23, 371-378. [CrossRef]

92. Girolami, V.; Mazzon, L.; Squartini, A.; Mori, N.; Marzaro, M.; Di Bernardo, A.; Greatti, M.; Giorio, C.; Tapparo, A. Translocation of neonicotinoid insecticides from coated seeds to seedling guttation drops: A novel way of intoxication for bees. J. Econ. Entomol. 2009, 102, 1808-1815. [CrossRef] [PubMed]

93. Faucon, J.P.; Aurieres, C.; Drajnudel, P.; Ribiere, M.; Martel, A.C.; Zeggane, S.; Chauzat, M.P.; Aubert, M.F.A. Experimental study on the toxicity of imidacloprid given in syrup to honey bees (Apis mellifera). Pest. Manag. Sci. 2005, 61, 111-125. [CrossRef] [PubMed]

94. Blacquiere, T.; Smagghe, G.; van Gestel, C.; Mommaerts, V. Neonicotinoids in bees: A review on concentrations, side-effects and risk assessment. Ecotoxicology 2012, 2, 973-992. [CrossRef] [PubMed]

95. Cresswell, J.E.; Page, C.J.; Uygun, M.B.; Holmbergh, M.; Li, Y.; Wheeler, J.G.; Laycock, I.; Pook, C.J.; de Ibarra, N.H.; Smirnoff, N.; et al. Differential sensitivity of honey bees and bumble bees to a dietary insecticide (imidacloprid). Zoology 2012, 115, 365-371. [CrossRef] [PubMed]

96. Krupke, C.H.; Hunt, G.J.; Eitzer, B.D.; Andino, G.; Given, K. Multiple routes of pesticide exposure for honey bees living near agricultural fields. PLoS ONE 2012, 7, e29268. [CrossRef] 
97. Yang, E.C. Abnormal foraging be $\neg$ havior induced by sublethal dosage of imidacloprid in the honey bee (Hymenoptera: Apidae). J. Econ. Entomol. 2008, 101, 1743-1748. [CrossRef]

98. Chan, D.S.; Prosser, R.S.; Rodríguez-Gil, J.L.; Raine, N.E. Assessment of risk to hoary squash bees (Peponapis pruinosa) and other ground-nesting bees from systemic insecticides in agricultural soil. Sci Rep. 2019, 9, 11870. [CrossRef]

99. Tosi, S.; Nieh, J.C. Lethal and sublethal synergistic effects of a new systemic pesticide, flupyradifurone (Sivanto®), on honeybees. Proc. R. Soc. B 2019, 286, 20190433. [CrossRef]

100. Guez, D. A common pesticide decreases foraging success and survival in honey bees: Questioning the ecological relevance. Front. Physiol. 2013, 4, 1-3. [CrossRef]

101. Henry, M.; Beguin, M.; Requier, F.; Rollin, O.; Odoux, J.-F.; Aupinel, P.; Aptel, J.; Sylvie Tchamitchian, S.; Decourtye, A. A common pesticide decreases foraging success and survival in honey bees. Science 2012, 336, 348-350. [CrossRef] [PubMed]

102. Sandrock, C.; Tanadini, M.; Tanadini, L.G.; Fauser-Misslin, A.; Potts, S.G.; Neumann, P. Impact of chronic neonicotinoid exposure on honeybee colony performance and queen supersedure. PLoS ONE 2014, 9, e103592. [CrossRef] [PubMed]

103. Tozzi, J. Memorandum: Is Varroa destructor or Neonicotinoid Pesticides Responsible for Bee Health Decline? Center for Regulatory Effectiveness: Washington, DC, USA, 2014; p. 20.

104. Watson, M.; McCarthy, M. Asian Honey Bee Swarm Carrying Varroa Mite Destroyed after Discovery in Brisbane Shipment. 2015. Available online: http://www.abc.net.au/news/2015-05-13/asian-honey-beeswarm-destroyed-nest-found-in-malaysia-shipment/6465672 (accessed on 13 May 2015).

105. Evans, J.D.; Spivak, M. Socialized medicine: Individual and communal disease barriers in honey bees. J. Invertebr. Pathol. 2010, 103, S62-S72. [CrossRef] [PubMed]

106. Mao, W.; Shuler, M.A.; Berenbaum, M.R. Honey constituents up-regulate detoxification and immunity genes in the western honey bee Apis mellifera. Proc. Natl. Acad. Sci. USA 2013, 110, 8763-8764. [CrossRef]

107. Pettis, J.S.; vanEngelsdorp, D.; Johnson, J.; Dively, G. Pesticide exposure in honey bees results in increased levels of the gut pathogen Nosema. Naturwissenschaften 2012, 99, 153-158. [CrossRef]

108. Baron, G.L.; Raine, N.E.; Brown, M.J.F. Impact of chronic exposure to a pyrethroid pesticide on bumblebees and interactions with a trypanosome parasite. J. Appl. Ecol. 2014, 51, 460-469. [CrossRef]

109. Wu, J.Y.; Smart, M.D.; Anelli, C.M.; Sheppard, W.S. Honey bees (Apis mellifera) reared in brood combs containing high levels of pesticide residues exhibit increased susceptibility to Nosema (Microsporidia) infection. J. Invertebr. Pathol. 2012, 109, 326-329. [CrossRef]

110. Brown, M.J.F.; Loosli, R.; Schmid-Hempel, P. Condition-dependent expression of virulence in a trypanosome infecting bumblebees? Oikos 2000, 91, 421-427. [CrossRef]

111. Partap, U.; Ya, T. The human pollinators of fruit crops in Maoxian county, Sichuan, China. Mt. Res. Dev. 2012, 32, 176-186. [CrossRef]

112. Partap, U. Cach crop farming in the Himalayas: The importance of the pollinator management and managed pollination. In FAO, Biodiversity and the Ecosystem Approach in Agriculture, Forestry and Fisheries; FAO Corporate Document Repository: Rome, Italy, 2003; Available online: http://www.fao.org/docrep/005/y4586e/y4586e11. htm\#P0_0 (accessed on 5 November 2019).

113. Castilhos, D.; Dombroski, J.L.D.; Bergamo, G.C.; Gramacho, K.P.; Gonçalves, L.S. Neonicotinoids and fipronil concentrations in honeybees associated with pesticide use in Brazilian agricultural areas. Apidologie 2019, 50, 657-668. [CrossRef]

114. Brühl, C.A.; Zaller, J.G. Biodiversity decline as a consequence of an inadequate environmental risk assessment of pesticides. Front. Environ. Sci. 2019, 7, 177. [CrossRef]

115. Burkle, L.A.; Marlin, J.C.; Knight, T.M. Plant-pollinator interactions over 120 years: Loss of species, co-occurrence, and function. Science 2013, 339, 1611-1615. [CrossRef] [PubMed]

116. Ghazoul, J. Buzziness as usual? Questioning the global pollination crisis. Trends Ecol. Evol. 2005, 20, 367-373. [CrossRef] [PubMed]

117. Schneider, S.S.; DeGrandi-Hoffman, G.; Smith, D.R. The African Honey Bee: Factors Contributing to a Successful Biological Invasion. Annu. Rev. Entomol. 2004, 49, 351-376. [CrossRef] [PubMed]

118. Moore, P.; Wilson, M.; Skinner, J. Africanized Bees: Better Understanding, Better Prepared. eXtention 2015, $1-12$. 
119. Basualdo, M.; Bedascarrasbure, E.; Jong, D. Africanized honey bees (Hymenoptera: Apidae) have a greater fidelity to sunflowers than European bees. J. Econ. Entomol. 2000, 93, 304-307. [CrossRef]

120. Kremen, C.; Williams, N.M.; Bugg, R.L.; Fay, J.P.; Thorp, R.W. The area requirements of an ecosystem service: Crop pollination by native bee communities in California. Ecol. Lett. 2004, 7, 1109-1119. [CrossRef] 